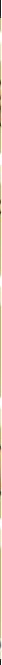

Editor:

Jaime Almansa Sánchez

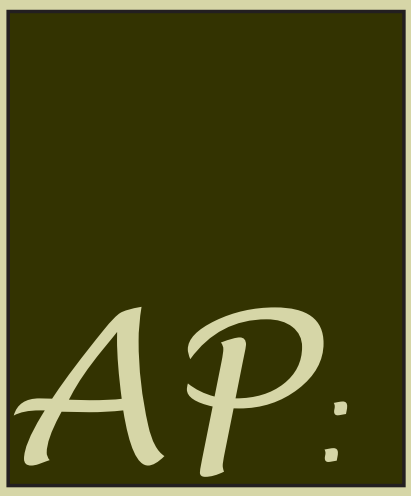

www.arqueologiapublica.es

Ontine Journat in Public Archaeology 


\title{
No news is better than evil news. Clearing up the way to face Alternative Archaeologies
}

\author{
Jaime ALMANSA SÁNCHEZ \\ JAS Arqueología S.L.U.
}

\section{Abstract}

While Archaeology started to take form as a professional discipline, Alternative Archaeologies grew in several ways. As the years went by, the image of Archaeology started being corrupted by misconceptions and a lot of imagination, and those professionals that were claiming to be scientists forgot one of their first responsibilities; the public. This lack of interest is one of the reasons why today, a vast majority of society believes in many clichés of the past that alternative archaeologists have used to build a fictitious History that is not innocent at all. From UFOs and the mysteries of great civilizations to the political interpretation of the past, the dangers of Alternative Archaeologies are clear and under our responsibility. This paper analyzes this situation in order to propose a strategy that may make us the main characters of the popular imagery in the mid-term. Since confrontation and communication do not seem to be effective approaches, we need a change in the paradigm based on Public Archaeology and the increase of our presence in everyday life.

\section{Key words}

Alternative Archaeology, Public Archaeology, Popular Culture, Public Action, Engagement

\section{Introduction: The nature of Alternative Archaeology}

Why does Alternative Archaeology exist? This is probably the first question we need to ask ourselves before continuing. To that end, defining Alternative Archaeology is essential. Tim Schadla-Hall defines it as "anything that disagrees with the generally accepted facts that archaeologists use to explain and reconstruct the past" (Schadla-Hall 2004: 256). Introducing a definition of Archaeology does not help at all. From the commonly accepted definitions to the latest ones like Gamble's that describes it as "whatever you want it to become" (Gamble 2008: 3), there is a range of terms, agrees and disagrees 
in which the border of the generally accepted facts is not very clear. Moreover, we all know there is not a single archaeological truth and discussion is the best way to create knowledge. So the answer to the initial question is very simple; Alternative Archaeology exists because there is not 'an Archaeology', and things that we assume today as true become 'alternative' tomorrow, or a common figure (Eller 2003). The public, that cannot easily access 'traditional' Archaeology, feel free to imagine and use 'their' Archaeology as a way to enjoy and participate in something they value.

Nevertheless, we cannot talk about Alternative Archaeology as one. Academia dictates the rules of what Archaeology is and is not, and everything else represents a huge amount of different situations and ideas that persist and people normally know. In this paper, I am going to differentiate two big groups that are strongly interconnected; on the one hand, we have this Archaeology directly related to political and identity matters. Issues like Nationalism have brought out a kind of Alternative Archaeology that can become dangerous for social and political stability. On the other hand, there is another group of 'researchers' worried about the unknown, the big mysteries of humanity, aliens, adventure, etc. They use Archaeology or 'archaeological facts' to prove the existence of things or situations that never happened. From the Bible to Atlantis, or the image of the sexy and brave archaeologist (in a way true), and although some of these theories can also be used for political reasons, the main damage of most of them is for Archaeology and archaeologists. They have a huge impact across the Media and popular culture, and they are the ones I will refer to in this paper. But where do they come from?

Some alternative views appear with a reason. Sometimes, it is a political one. Others, it is just a matter of money. And as I pointed out before, some of the views are just the results of the progress in the knowledge of our past. But there is an extravagance and an inherited curiosity for the unknown in humanity that make us look for something else. Scientific explanations are not enough and many people need a conspiracy or a mystery to believe in. An interesting research on this topic has been recently conducted by the Universty of Kent (Wood, Douglas and Sutton 2012), proving the absurdity of most of these beliefs. There are hundreds of alternative archaeologies, and the origin of most of them is very difficult to explain, but there is a common point; they do not recognize the 'official' point of view, and they are very successful. 


\section{The impact of Alternative Archaeology in popular culture}

The debate about the Public and Archaeology is open and rich. If we look at some recent works about Archaeology in Popular Culture (Almansa 2006; Holtorf 2007; Merriman 1991; Pokotylo and Guppy 1999; Ramos and Duggane 2000) we can see how the mostly widespread concepts about archaeology and archaeologists come from the media and other leisure activities, and are related to alternative conceptions of Archaeology. Why? Basically, because we are boring (or we are just not there) while they are hot.

Between the assumed 'real image' of the archaeologist and figures like Harrison Ford or Angelina Jolie, we have nothing to do. People love alternative archaeology (that they think is real) because it is attractive and they can watch it on TV. Anyway, it is strange how in countries like England, where they have had real and interesting archaeology on TV, alternative archaeology is still popular. So, where is the problem?

Now that we are starting to be worried about the Public, we are doing the same mistake again. We forget Society. Society is very complex and follows very complex rules. For example, I would like to refer to a study conducted in England about the cultural habits of English people according to the newspaper they read. It dates back to 1990 but represents contemporary society accurately. The general tendencies have not changed with the new Century.

\begin{tabular}{|c|c|c|c|}
\hline & Archaeological Sites & Monuments & Museums \\
\hline Independent & 20,4 & 45 & 53,4 \\
\hline Guardian & 19,2 & 43,4 & 56,5 \\
\hline Times & 13,9 & 43,4 & 51,5 \\
\hline Express & 6,5 & 27,8 & 30,1 \\
\hline Sun & 3,1 & 14,9 & 19,6 \\
\hline
\end{tabular}

Table 1. Percentage of people visiting different cultural attractions in the UK according to the newspaper they read (Stone and MacKenzie 1990). 
After this, we can argue that one of the determining factors is culture (and education). But we are to blame too. Is Archaeology for an elite? I would answer yes, because of the way it currently works in most of the world, and this is something we must be concerned about. Public Archaeology initiatives are useful, but we cannot expect a change in the public conception of archaeology in the short term, and let alone when alternative archaeology is so strongly represented in the Media.

What kind of Archaeology do people believe in?

The main source of information about archaeology (for 'outsiders') is Mass Media, mainly TV and the Internet. That is why the first thing we must do to approach the problem is to analyze them.

There are already some works on this topic (Holtorf 2007; IAPH 2007; Schablitsky 2007) and the quicker conclusion we can draw is that the image of archaeology we can get from Mass Media is confusing and usually wrong. The most popular topics in movies, news and web pages, are related to mystery, adventure, treasures and the unknown. Indiana Jones and Lara Croft might be the most famous 'archaeologists' and they are representatives of that exact image worldwide. But in almost every country we also find other representatives of alternative archaeology with an incredible success. Sometimes they are established as researchers of the unknown, and others they are taking advantage of special situations or events, but they always look for similar stuff, such as Nation, Aliens, God, etc.

Their success in the Media results in a huge amount of supporters and money to conduct their 'investigations'. For example, J. J. Benítez, one of the most famous Spanish alternatives, has sold more than 8 million books of his saga Caballo de Troya. After that, public TV invested several million Euros to make a 13-chapter documentary about the mysteries of the past, from Nazca to Cristobal Colón. Another example in Spain is Iker Jimenez. He conducts a radio programme, in one of the most-listened-to radio stations in Spain (Cadena SER), called Milenio 3. A few years ago, coinciding with the beginning of a new TV channel (Cuatro), he started the TV show Cuarto Milenio, broadcasted in primetime on Sunday nights until today, where he shows a different perspective from J.J. Benítez, maybe better. He only shows the mysteries, myths and tales from the past, leaving the interpretation to his guests in the set, although most of the time supporting the alternative one. While this happens, Spanish archaeologists continue doing their job. Their appearance in this or other TV shows is minimum 
and usually overshadowed by conspicuous comments and conclusions from the other guests. New TV shows like Sota Terra (in Catalan TV3) or Arqueomanía (in National TV La2) are the counterpoint, but are still showing a distorted image of archaeology.

Is Archaeology a boring subject nobody is concerned about? The papers I cited at the beginning of this chapter do not lead us to that conclusion. Normally, when asked about the interest of Archaeology or its value, a large percentage of society finds it very positive. Why do they follow Alternative Archaeology then? Is it maybe because they think they are being asked about that? We can answer this question in two ways; optimistic and pessimistic.

If we are optimistic, we can believe that people really know what Archaeology is, really like and enjoy it, but do not have it in their daily lives, so they cannot follow it. That explanation would be perfect. We would just need a little bit more of public presence to succeed. And looking at daily-life archaeology (tourism posters from countries like Greece, Peru or Syria) it seems quite possible.

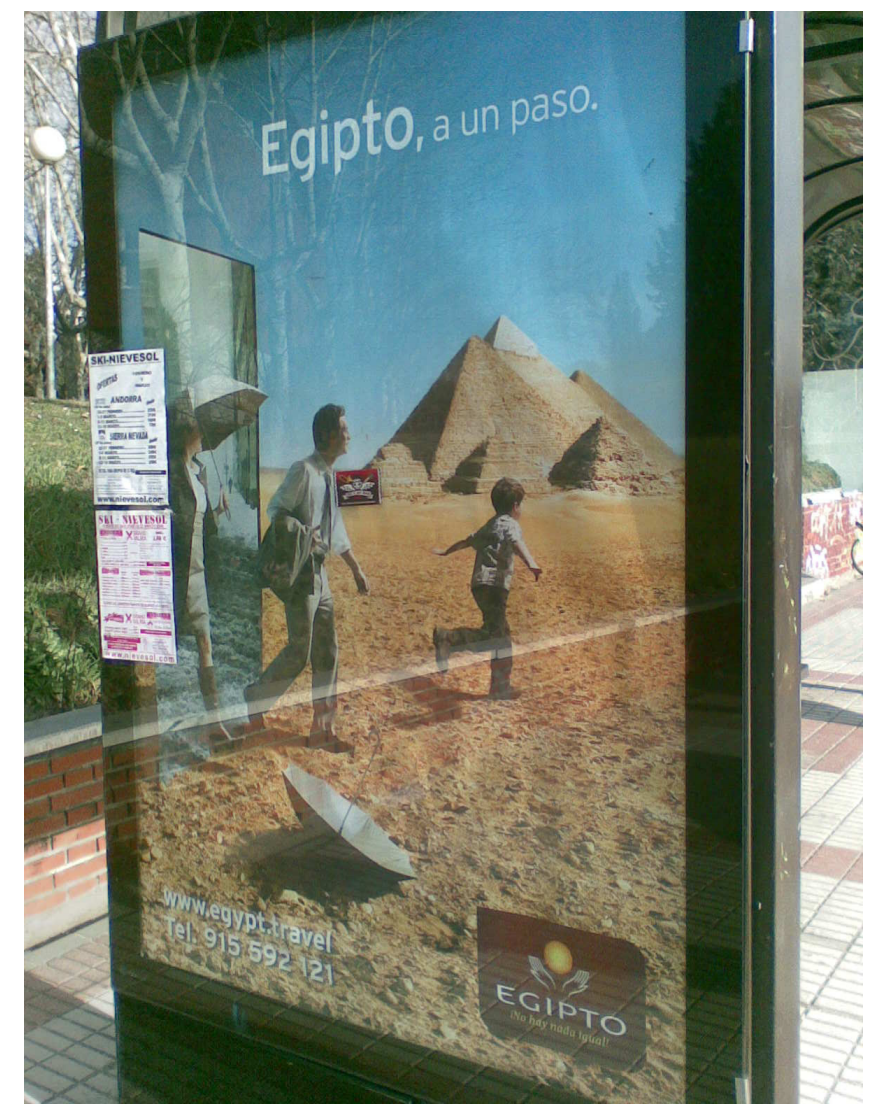

Figure 1. Visit Egypt from a bus stop in Madrid (Photo by author) 
If we are pessimistic, we can assume people are thinking about Indiana Jones or aliens in Egypt. In the survey I conducted in Spain (Almansa 2006: 10-12), a 98.6\% of the interviewees responded that Archaeology was a very valuable discipline (sometimes with a lot of energy), while being benevolent, only a 53\% knew what Archaeology was. How can you value something you do not know? The last survey of cultural habits in Spain (MCU 2011), shows around a 30\% interested in archaeology, but less than half of them actually visiting archaeological sites. What do they think archaeology is? That's a question to ask.

England is a characteristic example of how things are really complex. They have Archaeology on TV almost since TV started, with figures like Mortimer Wheeler (Moshenska and Schadla-Hall 2011), but alternative archaeology is powerful. Why? Obviously I do not have the answer, but something is failing when we cannot reach the public even with TV. Is Archaeology less interesting than aliens? Maybe we make Archaeology boring for the Public.

When I first saw Sir Mortimer Wheeler on TV (recently in a recording), I immediately remembered the sketch of the Monty Python's sketch in The Flying Circus. Time Team has been really successful, and The Big Dig is another example. On the other hand, authors like Hancock have become a social phenomenon writing about the mysteries of the past.

It is difficult to understand how this long course in TV Archaeology (Jordan 1981; Kulik 2006) has had no interference in the final image of Archaeology. Or did it? We just need to return to the previous idea of the complexity of society. There is a need to analyze the real conception that English society has of archaeology and, after that, we will be able to compare it with other initiatives and reach a conclusion. Anyway, there will always be an alternative conception of archaeology.

If we go back to the origins of archaeological mythologies, an important part of them come directly from the origins of Archaeology itself. Treasures were in a way usual when the first excavations took place. Some of the most important sites (mainly tombs and cities) were emptied before any modern methodology was improved. No research, no documentation, no context; just pots, jewellery, weapons, statues, etc. At the same time, the first humans were being discovered and from all these events and a bit of History, literature created an image of Archaeology that still persists today in today's society.

One example directly related to alternative archaeologies is Howard Phillips Lovecraft (Frigoli 2010). In his tales he assimilated the 
latest archaeological events, giving them a mythical or even magical background that sets the basis for ideas like the extraterrestrial 'touch' in the figure of Cthulhu. Then, the idea that primitive humans were not able to build or use what was ascribed to them did the rest. Over the years, new authors that did not necessarily follow him, delved into these topics, enforced by "Ooparts" (those objects supposed to be too advanced for their period) and other stories.

To summarize, we have in the scene; Archaeology and an image of Archaeology. Although for many people these two are the same, normally 'the image' is distorted. By what? Treasures, aliens, myths, adventures, and the legacy of the nineteenth century. Why? A mixture of Mass Media with alternative and apathetic archaeologists. What can we do about it?

\section{"No news is better than evil news." What can we do about Alternative Archaeology?}

The quote above has been attributed to King James I. Although it is also said that there is no such thing as bad publicity, the situation here is different. Alternative Archaeology does not in any way generate a positive publicity and sometimes it is even dangerous for 'official' Archaeology (as alternatives like to call it) and Society.

There have been many attempts to rebut as well as to accommodate alternative archaeology (Schadla-Hall 2004: 264-268). The results have not been very positive in none of the cases. Rebuttal results in more power for alternative archaeologists (they become 'martyrs'), while accommodation recognizes them as another stream and legitimizes their situation, thus also empowering them.

The New York Times has published an article titled Your Brain Lies to You (Wang and Aamodt 2008), in which the authors talked about something called "source amnesia". According to them, when we (in this case, archaeologists) try to rebut an alternative theory, we use to explain and analyze it. This is a way to promote it, as the fantastic theories of pseudoscience are usually 'interesting' enough to remain in our brains, while the refutation is most of the times forgotten. That means that each time we try to 'attack' alternative archaeology we are in reality reinforcing it, spreading their message, and creating a negative image of the archaeologist as a 'crying child'. 
What can we do after this panorama?

Over the past few years, I have tried to engage in dialogue with several people defending these ideas. So far, I can be proud of being able to help 'converting' one person after hours of reasoning with the inestimable help of a friend. This person (see Points of You in this volume) wrote for a well-known Internet publication (suite101) as head of Archaeology for Spain. He had a predominant position of authority to write and be believed by non-professionals. Today, his articles in other media are an example of well-documented views of the past, renouncing Alternative Archaeology.

Before him, I spent dozens of hours on Facebook groups and blogs, opening discussions about various incoherent theories of the past, and mainly, alien intervention in it [due to Facebook changes in the past couple of years and the fact that I was blocked from most of the groups, I cannot provide valid URLs, but you are free to write 'archaeology' in the search engine and surf]. I managed to identify three groups of people. First, those that really believed in their theories and had developed a strong archaeological basis and a missing link (the aliens) that was impossible to refute or prove. They usually follow the path of Zecharia Sytchin and similar authors, as well as the story of the Annunaki, which is probably the most expanded one, with references in popular culture from comics (Marvel's Silver Surfer) to TV series (mainly space-related ones, like Stargate, Smallville, Star Trek, Babylon 5 or Battlestar Galactica, although they are not directly mentioned). Second, those that followed these theories with no basis but with a strong belief that made them argue with a discourse full of misconceptions, contradictions and insults. They do not really know what they believe in, but have a radical position against Archaeology or anyone who tries to defend 'traditional' conceptions of the World. And third, those that directly are in a different perception of reality (religious) that makes them live in a kind of 'parallel universe' where our premises cannot be used. They are visionaries that really believe they come from other planets or have direct contact with a god. It is impossible to have any logical discussion with them, as it happens at totally different levels; on the one side, science, logic and tangible premises (which the other two groups also use or try to use), and on the other side, what could be defined as a spiritual and personal belief, such as New Age's Indigo children coming from other planets.

Normally, any direct discussion ends up with DNA issues, theoretical physics and religion, which makes it impossible to continue giving coherent arguments for the starting point topics. However, 
included in the first group, there are some 'original' alternatives that propose their own tangible discoveries. Some of them are inoffensive for archaeology, but others have been able to create a real problem. This is the case, for example, of the Bosnian Pyramids (see Forum 2 in this volume). Semir Osmanagic started a campaign in 2005 that is still spending millions of dollars of investment in the area, so that it can be declared World Heritage. He is not an archaeologist, but has become the most important Bosnian name in the field (see Forum 2 in this volume).

Fighting effectively these as well as other cases would require the exclusive dedication of dozens of archaeologists all around the world. And even with that, success would not be granted. The presence and power of Alternative Archaeologies are so prominent that it is really difficult to transform public conceptions and misconceptions of the past.

There is not any magical and fast solution. We cannot go and change people's minds in a second. The idea of a 'mental ray' that transforms the social conception of archaeology and converts people into fanatic Archaeology-consumers willing to give us the control of the world (like in cartoons) sounds amazing (or threatening), but is still impossible. Our only 'weapon' to fight Alternative Archaeology is Archaeology, but at least we can choose the tactics of this 'war'.

My proposal is based on engagement (in line with Holtorf 2005b). Dialogue is the best of the available options. It is true that accommodating alternative archaeology legitimizes their positions, but we need to do it that in order to rebut their visions of the past (or archaeology). An example is Neopaganism (Blain and Wallis 2004, 2006; Carpenter 1998). Neopaganists are perhaps the most popular and expanding alternatives we can find outside the political frame. This group has expanded internationally in close relation with the Celts. Moreover, it has appropriated several icons, such as Stonehenge that have no real archaeological relation to the period they think they belong to. They use Neolithic sites for a Bronze/Iron Age context with pre-Medieval characters, today. For years, they have been around with an incredible impact on society and popular culture, especially in the United Kingdom (Hutton 2007), but also in the whole Atlantic frame (see an interesting approach in the Spanish region of Asturias in Marín 2004, 2005). Others can be found in a fantastic book edited by Garrett Fagan that I did not have the opportunity to quote yet, but is of great value to understand these issues (Fagan 2006). 
"From Stonehenge to Las Vegas", the archaeo-appeal Holtorf talks about (Holtorf 2005a: 150-160) has lots to do with this increase of the popularly accepted ideas about archaeology and the past. It shows the popular interest in Archaeology and the attractiveness of our work, but an important part of it does not come from Archaeology. Alternative Archaeologies, from popular culture, have spread out an image of Archaeology and archaeologists that has been successful. The alternative-appeal is sure, and we just need to look at the numbers to realize its power, but where is the original archaeo-appeal?

Besides this engagement with alternative groups, the main 'weapon' we have to fight Alternative Archaeology is Archaeology itself. But what failed then in the English experience? Perhaps nothing. One of the factors we have to take into account is the number of people who now know more about Archaeology.

We will probably be incapable of changing the distorted image that Alternative Archaeology offers, but we can promote our work and our results in a wider (a wider group of people/public) and in a more public way. If we still believe in phantoms, legends or God, there will always be room for an alternative interpretation of the past. We cannot change people's beliefs, but at least we can offer a different image of our work. In essence, we shall not impose, but propose.

Little by little, by promoting dialogue combined with archaeological action, we will be able to get more people to join the 'Club of the Real Archaeology'. Alternatives will always be there, but there will come a time when a vast majority of society will recognize and value Archaeology as it really is. It might continue to be an issue for generations, but this is the only safe and sustainable strategy. It could be named 'the silent killer' strategy.

However, our battle does not end there and, at the same time, we should deal with other misconceptions of the past (and the present) that 'official' archaeology has traditionally reinforced, such us those related to gender, evolution/development or class.

We can prevail over Alternative Archaeology. All we need is humility and commitment. Will we be able to do it? 
Chapter 1.

Archaeology does not face the public.

Alternative Archaeologies get the

support.

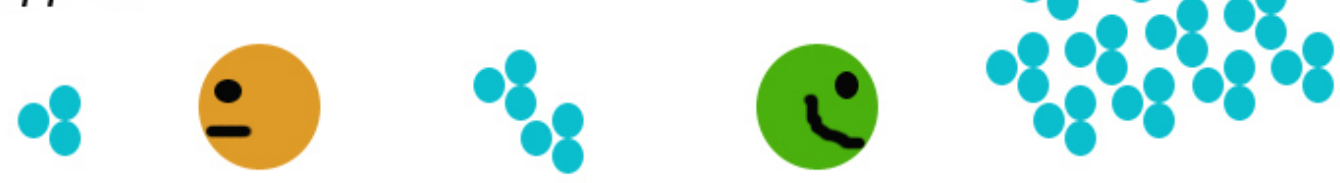

Chapter 2.

A frontal attack against Alternative Archaeology will have worse results.
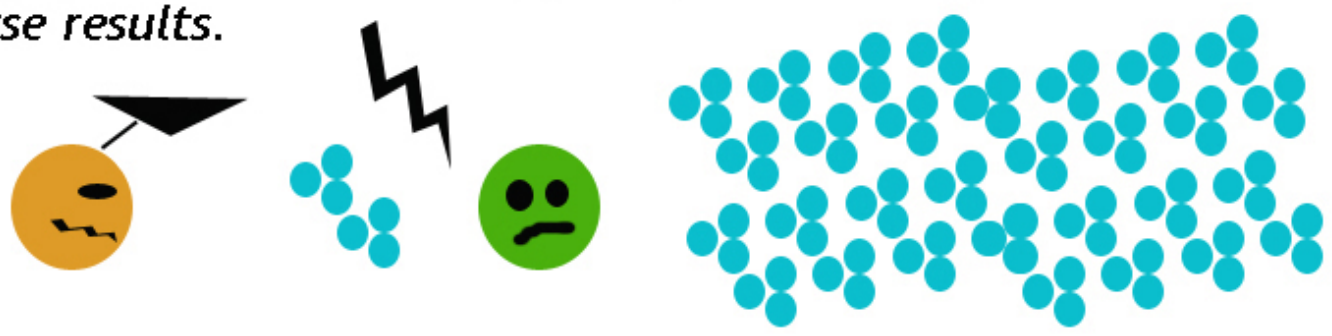

Chapter 3.

Facing the public properly, we will little by little gain them.
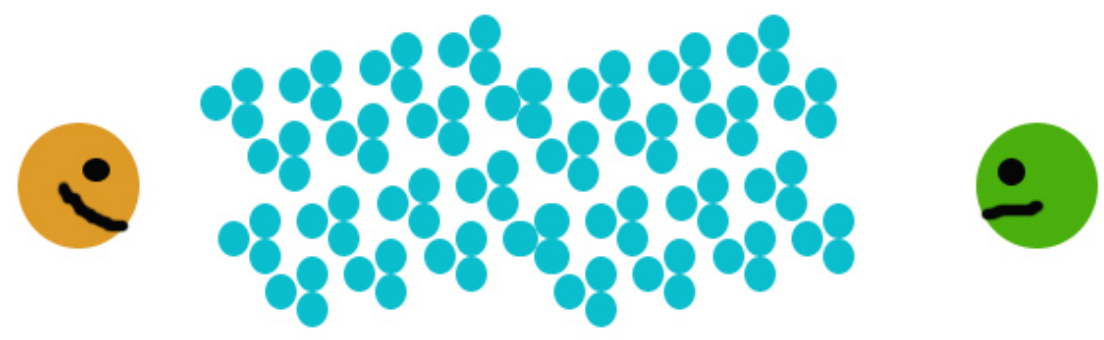

Chapter 4.

And one day... people will follow us.

And Alternative Archaeologies will be merely anecdotes
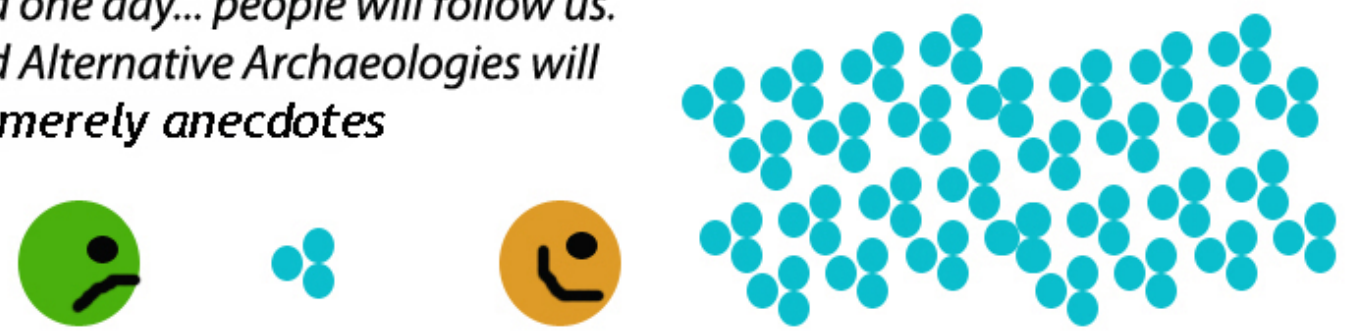

Figure 2. 'The silent killer' strategy, or how with time, commitment and patience we can prevail over Alternative Archaeologies (by author). 


\section{Conclusion}

Raising awareness about the importance of Archaeological Heritage and what Archaeology really is represents a very important issue for us as a collective. The current widespread image of Archaeology is an obstacle to the public diffusion of our work and the preservation of our past.

Alternative Archaeology is directly linked to more important problems, such as those related to politics, which I did not deal with in this paper or the struggle with the construction world that in countries like Spain represents the sustenance and, at the same time, the main reason of destruction for Archaeology.

A common approach to all these issues is closely related to Education. 'The silent killer' strategy which I proposed in this paper in order to fight Alternative Archaeology is nothing else than a good Education programme conducted from Archaeology. We cannot forget that the rapid expansion of Pseudoscience originates from the ignorance and lack of access to Science that the public have. Archaeology, as we have just seen, is not an exception to this rule, but 'plays' with an advantage due to the already existing society's active interest in it.

Education must be the central point of our work. The increasing knowledge about Archaeology among the public is the only sustainable way to effectively change the views of the past and the profession. This education does not only have to be oriented to children, as it usually is, but also focused on all society levels and especially on those areas in direct contact with us. But we cannot wait until someone else does it. It is our responsibility.

We must do something about Alternative Archaeology, but with such an intricate panorama it becomes difficult to develop a common strategy. For the time being, we do not need a common approach; we must only have two ideas in mind: Communication (for the alternatives) and Action (for the public). With these two premises 'the silent killer' strategy can work, slowly but safely, towards a better understanding of Archaeology.

Because together, we can. 


\section{Bibliography}

Almansa, J. 2006. La imagen popular de la Arqueología en Madrid. ArqueoWeb 8(1) [URL: http://www.ucm.es/info/arqueoweb/ pdf/8-1/almansa.pdf]

Blain, J. and Wallis, R.J. 2004. Sacred sites, contested rites/rights: contemporary pagan engagements with the past. Journal of Material Culture 9(3), 237-261.

Blain, J. and Wallis, R.J. 2006. Past and Pagan Practices: moving beyond Stonehenge. Public Archaeology 5(4), 211-222.

Carpenter, D. 1998. Symbolic stupidity. The right times 2, 24.

Eller, C. 2003. The religious use of prehistoric imagery in contemporary goddess spirituality. Public Archaeology 3, 7787.

Fagan, B. (Ed.) 2006. Archaeological Fantasies. London: Routledge.

Frigoli, R. 2010. Las excavaciones de R'lyeh. La arqueología como método, la prehistoria como idea y la literatura fantástica de HP Lovecraft. Madrid: JAS Arqueología.

Gamble, C. 2008 [2nd ed.]. Archaeology. The basics. London: Routledge.

Holtorf, C. 2005a. From Stonehenge to Las Vegas. Archaeology as Popular Culture. Walnut Creek: Alta Mira Press.

Holtorf, C. 2005b. Beyond crusades: how (not) to engage with alternative archaeologies. World Archaeology 37(4), 544551.

Holtorf, C. 2007. Archaeology is a brand. The meaning of Archaeology in Contemporary Popular Culture. Walnut Creek: Left Coast Press.

Hutton, R. 2007. The Druids: A History. London: Hambledon Press. 
IAPH 2007. Patrimonio cultural y medios de comunicación. PH cuadernos 21. Sevilla: Instituto Andaluz de Patrimonio Histórico.

Jordan, P. 1981. Archaeology and television. In J. Evans, B. Cunliffe and C. Renfrew (eds). Antiquity and Man: Essays in honour of Glynn Daniel. London: Thames and Hudson, 207-213.

Kulik, K. 2006. Archaeology and British Television. Public Archaeology 5(2), 75-90.

Marín, C. 2004. Historiografía de la Edad del Hierro en Asturias. Complutum 15, 75-97.

Marín, C. 2005. El celtismo asturiano. Una perspectiva arqueológica. Gallaecia 24, 309-333.

MCU 2011. Encuesta de hábitos y prácticas culturales en España 2010-2011. Madrid: Ministerio de Cultura.

Merriman, N. 1991. Beyond the glass case. The Past, the Heritage and the Public in England. Leicester: Leicester University Press.

Moshenska, G. and Schadla-Hall, T. 2011. Mortimer Wheeler's Theatre of the Past. Public Archaeology 10(1), 46-55.

Pokotylo, D. and Guppy, N. 1999. Public opinion and archaeological heritage: views from outside the profession. American Antiquity 64, 400-416.

Ramos, M. and Duganne, D. 2000. Exploring public perceptions and attitudes about Archaeology. Report from the SAA. [URL: http://www.saa.org/pubedu/nrptdraft4.pdf]

Schablitsky, J. M. (ed.) 2007. Box office Archaeology. Refining Hollywood's portraits of the past. Walnut Creek: Left Coast Press.

Schadla-Hall, T. 2004. The comforts of unreason: the importance and relevance of alternative archaeology. In N. Merriman (ed.) Public Archaeology. London. Routledge, 255-271. 
Wang, S. and Aamodt, S. 2008. Your Brain Lies to You. New York Times, 27 June.

Wood, M.J., Douglas, K.M. and Sutton, R.M. 2012. Dead and alive: Beliefs in Contradictory Conspiracy Theories. Social Psychological and Personality Science. [Published online before print on 25 January 2012] 


\section{AP: Ontine Journat in Public Archaeology}

\section{Editor:}

Jaime Almansa Sánchez

Email: almansasanchez@gmail.com

Assistant editor:

Elena Papagiannopoulou

Edited by:

JAS Arqueología S.L.U.

Website: www.jasarqueologia.es

Email: jasarqueologia@gmail.com

Address: Plaza de Arteijo 8, T-2, 28029 - Madrid (Spain)

--

Cover Image: Storyboard for a PSA in Philly (H. Winograd and M. Haas)

Copyright (C) 2012 JAS Arqueología S.L.U. (edition) \& Authors (content)

ISSN: $2171-6315$

Quotation:

Almansa, J. 2012. No news is better than evil news. Clearing up the way to face Alternative Archaeologies. AP Journal Vol. 2, 122-136.

AP Journal is a peer-reviewed journal devoted exclusively to Public Archaeology. It is freely distributed online on the Website:

$$
\text { www.arqueologiapublica.es }
$$

You can also follow us on:

Blogger:

=- http://arqueologiapublica.blogspot.com/

Twitter:

http://twitter.com/APjournal

Facebook:

http://www.facebook.com/APJournal 